Supplement of Clim. Past, 16, 65-78, 2020

https://doi.org/10.5194/cp-16-65-2020-supplement

(C) Author(s) 2020. This work is distributed under

the Creative Commons Attribution 4.0 License.

(c) (1)

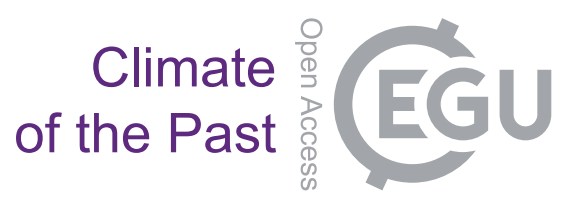

Supplement of

\title{
Joint inversion of proxy system models to reconstruct paleoenvironmental time series from heterogeneous data
}

\section{Gabriel J. Bowen et al.}

Correspondence to: Gabriel J. Bowen (gabe.bowen@utah.edu)

The copyright of individual parts of the supplement might differ from the CC BY 4.0 License. 


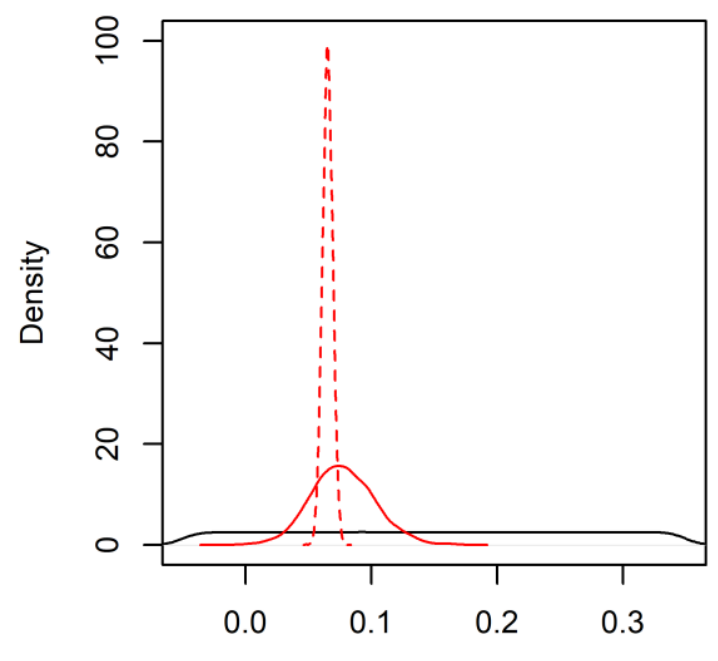

Uvigerina Mg/Ca T sensitivity $\left(\alpha_{2}\right)$

Figure S1: Foraminiferal $\mathrm{Mg} / \mathrm{Ca}$ temperature sensitivity parameter prior and posterior estimates from independent Bayesian inversion using calibration data only. Dashed red line shows posterior estimated from core-top data described in main text. Solid red line is the posterior estimate based on the downcore calibration approach of Elderfield et al. (2010), using core-top values from site 1123 and the Chat $1 \mathrm{~K}$ core as representative of Holocene foraminiferal $\mathrm{Mg} / \mathrm{Ca}$ and $\delta^{18} \mathrm{O}$ values and site 1123 data from 25 $15 \mathrm{ka}$ to represent the LGM condition, plus an independent estimate of LGM to Holocene seawater $\delta^{18} \mathrm{O}$ change of $-1.1(1 \sigma=0.1)$ from Adkins et al. (2002). The black line give the prior distribution applied in both analyses. 

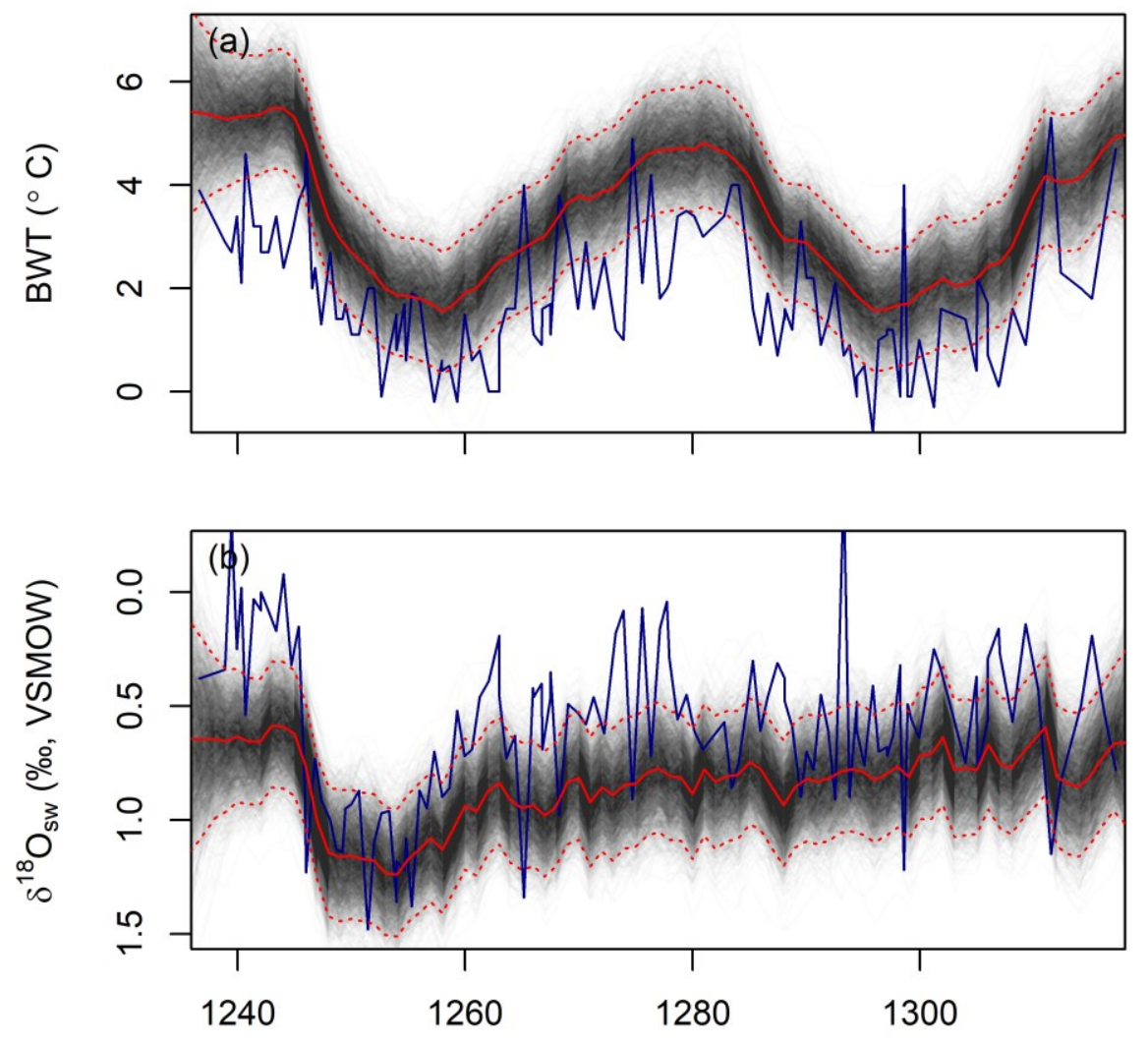

Age (ka)

Figure S2: Paleoenvironmental reconstructions from single-site JPI of data from site U1385. (a) Bottom water temperature, and (b) seawater $\delta^{18} \mathrm{O}$. Blue line shows the reconstruction of Birner et al. (2016) based on the Elderfield et al. (2010) down-core calibration. All other symbols as in Figure 2. 

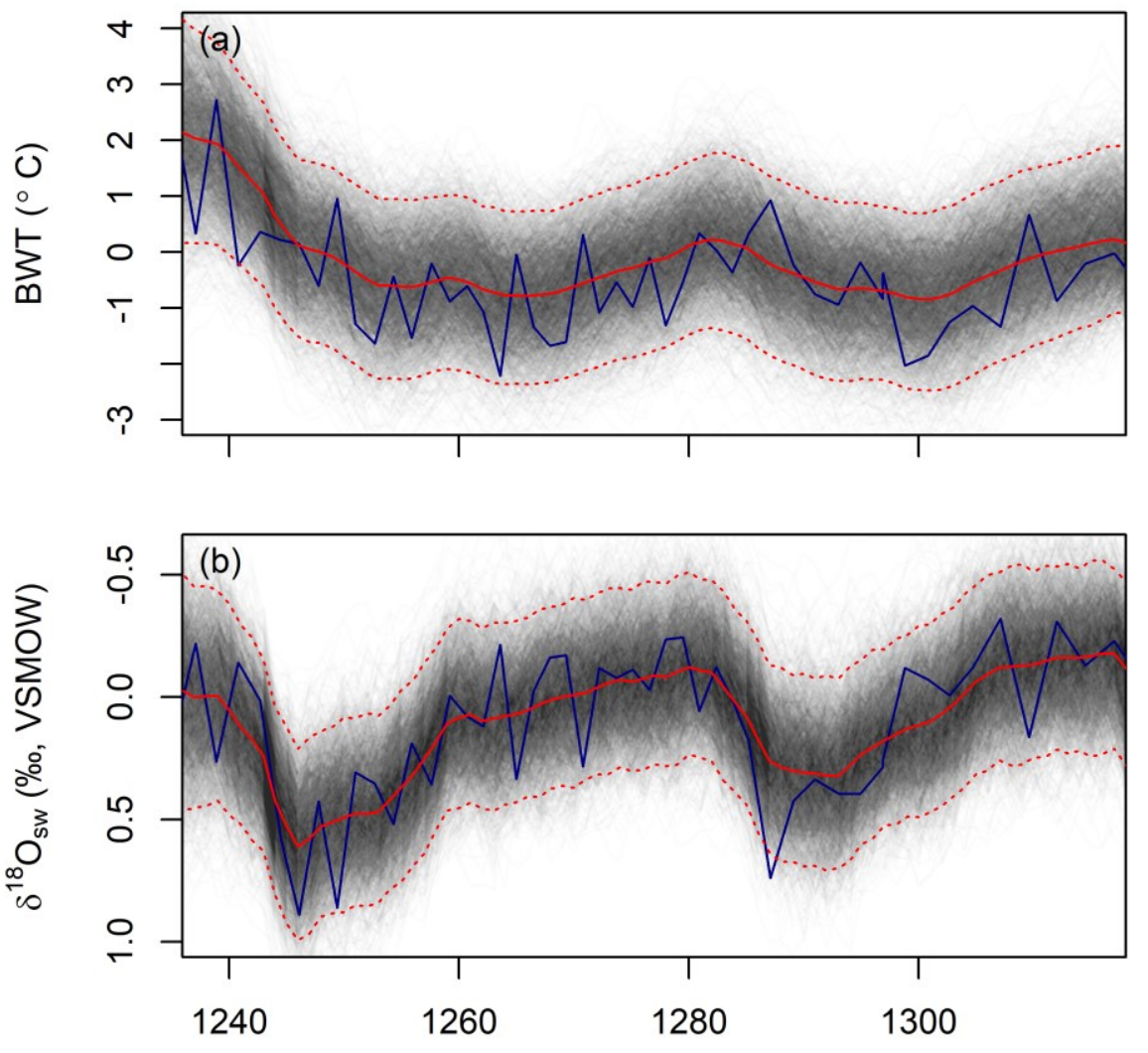

Age (ka)

Figure S3: Paleoenvironmental reconstructions from single-site JPI of data from site 1123. (a) Bottom water temperature, and (b) seawater $\delta^{18} \mathrm{O}$. Blue line shows the reconstruction of Elderfield et al. (2012) based on the Elderfield et al. (2010) down-core calibration. All other symbols as in Figure 2. 

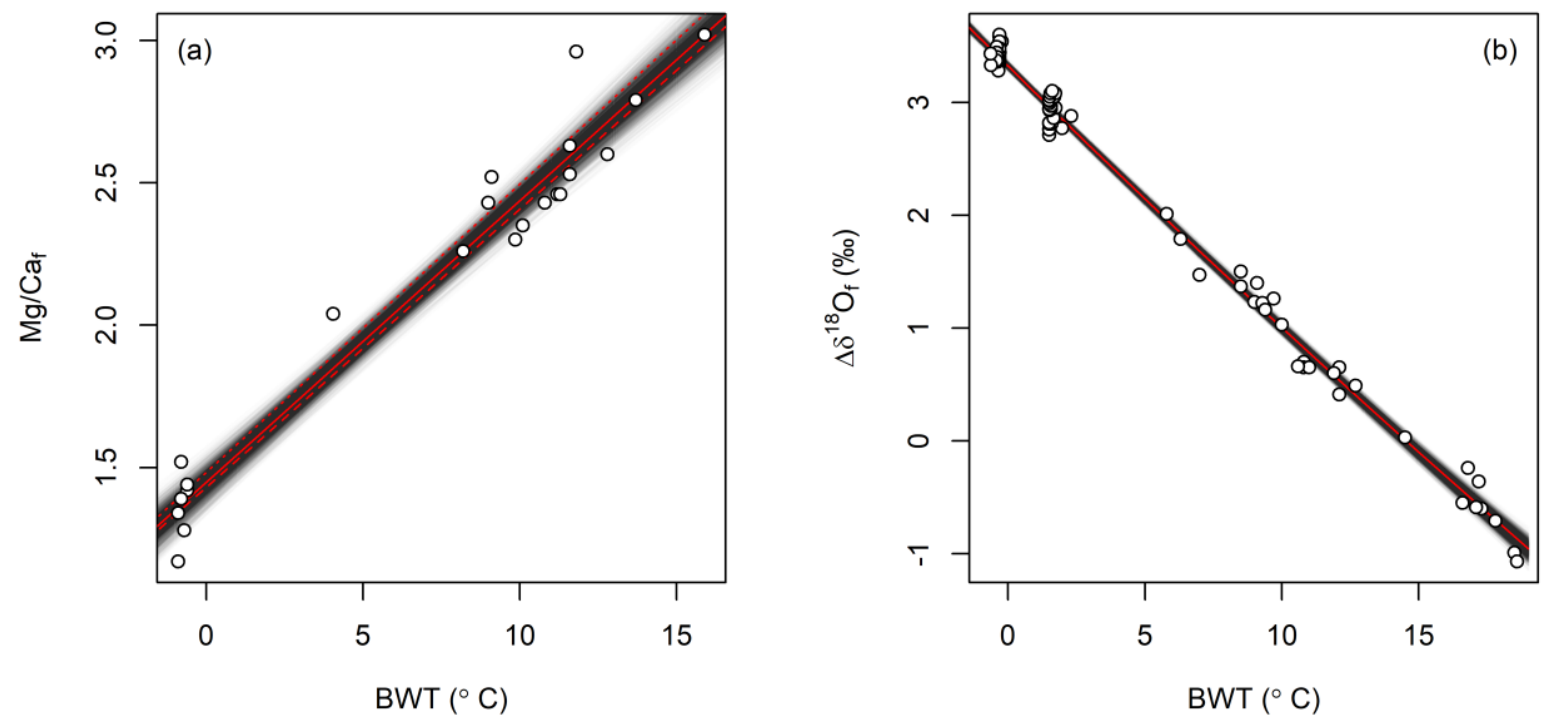

Figure S4: Calibration data and posterior draws from the site 806 analysis showing proxy model relationships between bottom water temperature (BWT) and (a) O. umbonatus $\mathrm{Mg} / \mathrm{Ca}$ (Lear et al., 2015) or (b) Cibicidoides ${ }^{18} \mathrm{O}$-enrichment $\left(\Delta \delta^{18} \mathrm{O}_{f}=\delta^{18} O_{f}-\delta^{18} O_{s w}\right.$, values in \%o VPDB and VSMOW, respectively) (Marchitto et al., 2014). Black lines show individual draws from the posterior; red lines show the median relationship. Posterior draws and red solid line shown in (a) use seawater $\mathrm{Mg} / \mathrm{Ca} a_{s w}=3.5$, dotted and dashed lines use $M g / C a_{s w}=1.5$ and 5.5, respectively. White-filled circles show individual calibration data. 


\section{References}

Adkins, J. F., McIntyre, K., and Schrag, D. P.: The salinity, tempreature, and $\delta^{18} \mathrm{O}$ of the glacial deep ocean, Science, 298, 1769-1773, 2002.

Birner, B., Hodell, D. A., Tzedakis, P. C., and Skinner, L. C.: Similar millennial climate variability on the Iberian margin during two early Pleistocene glacials and MIS 3, Paleoceanography, 31, 203-217, 2016. Elderfield, H., Greaves, M., Barker, S., Hall, I. R., Tripati, A., Ferretti, P., Crowhurst, S., Booth, L., and Daunt, C.: A record of bottom water temperature and seawater $\delta^{18} \mathrm{O}$ for the Southern Ocean over the past $440 \mathrm{kyr}$ based on $\mathrm{Mg} / \mathrm{Ca}$ of benthic foraminiferal Uvigerina spp, Quaternary Science Reviews, 29, 160-169, https://doi.org/10.1016/j.quascirev.2009.07.013, 2010.

Elderfield, H., Ferretti, P., Greaves, M., Crowhurst, S., McCave, I. N., Hodell, D., and Piotrowski, A. M.: Evolution of Ocean Temperature and Ice Volume Through the Mid-Pleistocene Climate Transition, Science, 337, 704, 2012.

Lear, C. H., Coxall, H. K., Foster, G. L., Lunt, D. J., Mawbey, E. M., Rosenthal, Y., Sosdian, S. M., Thomas, E., and Wilson, P. A.: Neogene ice volume and ocean temperatures: Insights from infaunal foraminiferal $\mathrm{Mg} /$ Ca paleothermometry, Paleoceanography, 30, 1437-1454, 2015.

Marchitto, T. M., Curry, W. B., Lynch-Stieglitz, J., Bryan, S. P., Cobb, K. M., and Lund, D. C.: Improved oxygen isotope temperature calibrations for cosmopolitan benthic foraminifera, Geochim. Cosmochim. Acta, 130, 1-11, https://doi.org/10.1016/i.gca.2013.12.034, 2014. 